Margenau, E. L., P. B. Wood, C. A. Weakland, and D. J. Brown. 2019. Trade-offs relating to grassland and forest mine reclamation approaches in the central Appalachian region and implications for the songbird community. Avian Conservation and Ecology 14(1):2. https://doi.org/10.5751/ ACE-01304-140102

Copyright (C 2019 by the author(s). Published here under license by the Resilience Alliance.

Research Paper

\title{
Trade-offs relating to grassland and forest mine reclamation approaches in the central Appalachian region and implications for the songbird community
}

\author{
Eric L. Margenau ${ }^{1}$, Petra B. Wood ${ }^{2}$, Cathy A. Weakland ${ }^{3}$ and Donald J. Brown ${ }^{4,5}$ \\ ${ }^{1}$ West Virginia Cooperative Fish and Wildlife Research Unit, School of Natural Resources, West Virginia University, \\ Morgantown, WV, USA, ${ }^{2}$ U.S. Geological Survey, West Virginia Cooperative Fish and Wildlife Research Unit, West Virginia \\ University, Morgantown, WV, USA, ${ }^{3}$ Department of Biology and Chemistry, Spring Arbor University, Spring Arbor, MI, USA, \\ ${ }^{4}$ School of Natural Resources, West Virginia University, Morgantown, WV, USA, ${ }^{5}$ U.S. Forest Service, Northern Research \\ Station, Parsons, WV, USA
}

\begin{abstract}
Surface mining in the Appalachian region (USA) converts large areas of mature forest to early successional habitat. This shift in landscape structure has the potential to reduce habitat availability and suitability for forest-dwelling songbirds by reducing and fragmenting mature forest, but also to increase habitat availability for grassland- and shrubland-associated songbirds. We examined the influence of mountaintop mining/valley fill (MTMVF) reclamation habitats (grassland, shrubland, and remnant forest) on songbird community composition and abundance at three former MTMVF mines in southwestern West Virginia, relative to intact forest. We quantified the songbird community in 1999 and 2000 using point counts arranged throughout the mine complexes to assess landscape composition of the songbird community. Community analysis showed songbirds had strong associations with their respective guild based on species habitat preferences. Although remnant and intact forest treatments had similar species compositions, the forest interior guild had greater richness in intact rather than remnant forest. Total species richness was greatest in the reclaimed shrubland treatment. Focal species analysis followed similar trends as community assessments, because most species abundances within treatment types were strongly associated with species habitat preferences. Our results indicate that reclamation habitat decisions, i.e., grasslands versus forests, can have large effects on avian community composition. Determining appropriate mine restoration actions depends on the suite of species desired for long-term occupancy and their conservation priority.
\end{abstract}

\section{Compromis relatifs aux approches de remise en état de mines en prairie ou forêt dans la région centrale des Appalaches et répercussions sur la communauté de passereaux}

RÉSUMÉ. L'exploitation de mines à ciel ouvert dans la région des Appalaches (É.-U.) a entrainé la conversion de vastes secteurs de forêts matures en milieux de début de succession. Ce changement dans la structure du paysage peut engendrer une réduction de la disponibilité et de la qualité des milieux pour les passereaux forestiers en réduisant et fragmentant les forêts matures, mais peut aussi entrainer une augmentation de la disponibilité de milieux pour les passereaux de prairies et d'arbustaies. Nous avons examiné l'effet de la remise en état (en prairie, arbustaie ou forêt résiduelle) d'anciens sites miniers situés au sommet de montagnes ou dans des vallées remblayées (SMVR) sur la composition et l'abondance des communautés d'oiseaux à trois anciennes mines SMVR dans le sud-ouest de la Virginie-Occidentale, comparativement à des forêts intactes. Nous avons déterminé la composition des communautés d'oiseaux à l'échelle du paysage au moyen de dénombrements par points d'écoute répartis dans l'ensemble des complexes miniers en 1999 et 2000. L'analyse des communautés a révélé que les passereaux étaient fortement associés selon leur guilde respective fondée sur leurs préférences d'habitat. Même si les forêts résiduelles et intactes avaient une composition spécifique similaire, la richesse de la guilde d'oiseaux d'intérieur de forêt a été plus élevée dans les forêts intactes que les forêts résiduelles. Le nombre d'espèces le plus élevé a été trouvé dans les arbustaies restaurées. L'analyse par espèce a montré les mêmes tendances que celles des communautés, parce que l'abondance de la plupart des espèces pour un même type de traitement était fortement liées aux préférences d'habitat des espèces. Nos résultats indiquent que les décisions relatives à la remise en état de sites miniers, c.-à-d. en prairie ou forêt, peuvent avoir des répercussions importantes sur la composition des communautés aviaires. La détermination des actions appropriées pour la restauration de mines dépend des espèces désirées à long terme et de leur priorité de conservation.

Key Words: central Appalachians; mine reclamation; songbird community; surface mining 


\section{INTRODUCTION}

The continued modification of forested landscapes from surface mining and their subsequent revegetation represents a potential crossroads for mine reclamation practices. Because of the degree of land modification associated with surfacing mining, reclamation decisions can influence long-term occupancy of wildlife communities. In the central Appalachian region of the United States, reclamation can generally be split into the traditional grassland reclamation approach and the newer forest reclamation approach. The grassland approach plants fastgrowing grasses (often nonnative) to reduce soil erosion and increase vegetative cover, in accordance with the Surface Mining Control and Reclamation Act of 1977 (SMCRA). The forest approach is a newer approach that was developed by the Appalachian Regional Reforestation Initiative to encourage the restoration of forests on reclaimed surface mines and help establish forests through natural succession while still meeting the requirements of SMCRA (Angel et al. 2005). These two approaches have diverging long-term outcomes that affect plant composition, which in turn affect wildlife communities.

Early successional plant communities, primarily grasslands, are often predominant following mine closure (Chaney et al. 1995, Zipper et al. 2011). The outcome of revegetating primarily with grasses is the creation of extensive grasslands on mines, which benefits grassland birds (DeVault et al. 2002, Galligan et al. 2006, Wood and Ammer 2015). In North America, grassland bird populations have substantially declined over the last several decades (Ribic et al. 2009, Sauer et al. 2014) because of reduced areas in grasslands from land conversion, e.g., agriculture, or woody encroachment (Coppedge et al. 2001, Grant et al. 2004). Grassland plant communities can remain on mines for an extended period of time ( $>20$ years; Ingold and Dooley 2013, Wood and Ammer 2015) because of poor soil quality, which inhibits establishment and growth of natural woody vegetation (Chaney et al. 1995) and creates an arrested state of succession (Wickham et al. 2013). Despite the benefits of grassland reclamation for grassland songbirds, grassland communities are novel in the central Appalachians (Hall 1983) and may not contribute functional ecosystem services when compared with forests, e.g., carbon storage and watershed and water quality protection (Zipper et al. 2011).

The forest approach attempts to expedite forest succession on mine lands and return landscapes to their premining land cover by limiting soil compaction and planting native trees (Angel et al. 2005). Within the central Appalachians (eastern Kentucky, northeastern Tennessee, southwestern Virginia, and southern West Virginia), the primary land cover is forest (89\%; Sayler 2008), and forest loss and fragmentation are largely driven by natural resource extraction, e.g., mining (Sayler 2008, Townsend et al. 2009, Drummond and Loveland 2010, Palmer et al. 2010). Additionally, the central Appalachian region provides core forest, i.e., areas of forest $>100 \mathrm{~m}$ from any forest edge, for forest-dwelling birds that are experiencing substantial population declines throughout their range, e.g., Cerulean Warbler (Setophaga cerulea) and Wood Thrush (Hylocichla mustelina; Sauer et al. 2014). Because of forest birds' reliance on core forest habitat (Becker et al. 2015, Farwell et al. 2016), the Appalachian region (Bird Conservation Region 28 [BCR 28]; see Fig. 1) is important to the conservation of North American forest bird populations. However, few studies have reported mining's negative effects on forest bird species (Weakland and Wood 2005, Wood et al. 2006, Becker et al. 2015) or whether these can be reduced or offset. Despite the limited data relating to the forest approach and the trade-offs for forest birds, the forest reclamation approach nonetheless provides a framework that focuses on reforestation and the return of forest-based ecosystems (Zipper et al. 2011, McDermott et al. 2013).

Fig. 1. Location of mountaintop mining complexes in southwestern West Virginia, USA. Map on the right represents mine complexes (shaded black) used to assess mountaintop mining/valley fill effects on the songbird community. Top left map shows location of West Virginia (shaded gray) and Bird Conservation Region 28 (crosshatched region). Bottom left map shows county locations (shaded gray) where study was conducted within West Virginia.

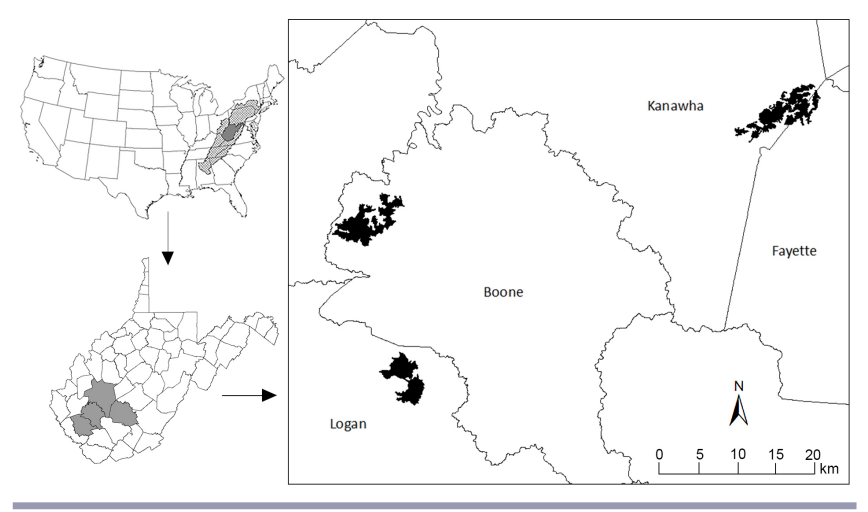

The decision to reclaim mined lands with either a grassland or forest approach can be based on the suite of species desired for long-term occupancy, but the return of premining bird communities is important to factor into reclamation objectives as well. Our purpose was to evaluate potential trade-offs between the grassland and forest reclamation approaches by quantifying the songbird community on mountaintop mining/valley fill (MTMVF) complexes and adjacent forest patches in southern West Virginia. A large portion of the Appalachian region (BCR 28; Fig. 1) is available for surface mining activities ( 40\%; Fig. 2); thus it is important to evaluate the potential trade-offs between grassland reclamation versus forest reclamation and their effects on songbird conservation for future application in the Appalachian region. Because of songbird habitat associations, we expect that songbirds will be closely related with their a priori habitat associations on MTMVF complexes and adjacent forest patches, although this has not been explicitly tested relative to mine reclamation. Our results highlight gains and losses in the avian community that will help reclamation practitioners develop guidelines when managing mine landscapes in the Appalachian region.

\section{METHODS}

Study areas included 3 MTMVF complexes and adjacent unmined mature forest areas in Boone, Logan, Kanawha, and Fayette counties in southwestern West Virginia (Fig. 1). We categorized four treatments represented within the study area: reclaimed grassland, reclaimed shrubland, remnant forest, and intact forest. Reclaimed mine landscapes on our MTMVF sites included areas primarily reclaimed to grassland $(1672,1819$, and 
2003 ha on each of the 3 sites), reclaimed shrubland areas $(0,428$, and $508 \mathrm{ha}$ ), and remnant forest patches (hereafter termed remnant forest; 155, 214, and 339 ha; Fig. 3). Grassland areas were planted during the reclamation process primarily with nonnative grasses and legumes such as tall fescue (Festuca arundinacea), sericea lespedeza (Lespedeza cuneate), orchard grass (Dactylis glomerata), and perennial rye grass (Lolium perenne). Grassland areas were 5-19 years postreclamation at the time of the study. Shrubland areas consisted primarily of shrubs and pole-sized trees $(0-8 \mathrm{~cm}$ diameter-at-breast height [DBH]) and were approximately 13-27 years postreclamation. Vegetation in shrubland habitats included species seeded or planted during reclamation such as tall fescue, sericea lespedeza, autumn olive (Elaegnus umbelleta), black locust (Robinia pseudoacacia), scotch pine (Pinus sylvestris), and species that regenerated naturally including goldenrod (Solidago spp.), red maple (Acer rubum), American sycamore (Platanus occidentalis), tuliptree (Liriodendron tulipifera), multiflora rose (Rosa multiflora), and blackberry/ raspberry (Rubus spp.). Shrublands on mine complexes comprised little of the total reclaimed area at our study areas (936 of 6430 ha, $\sim 14 \%$ of all reclaimed area), indicating the limited use of shrubland reclamation techniques at the time (ca. 1980s). Mine ages were the estimated year that sites were reclaimed based on information provided by the mining companies. We defined treatments based on vegetation characteristics, so lack of succession on older grassland sites resulted in an age overlap between grasslands and shrublands. Forest areas were primarily mixed mesophytic hardwood forest that were $\sim 60-80$ years old and were composed mostly of red, white, and black oak (Quercus rubra, $Q$. alba, and $Q$. velutina); pignut, bitternut, and shagbark hickory (Carya glabra, C. cordiformis, and C. ovata); red and sugar maple ( $A$. saccharum); and tuliptree. Remnant forests were patches of mature forest surrounded by reclaimed mine land on at least 3 sides. Intact forest sites were forested areas undisturbed by mining activities and were in close proximity to MTMVF areas either within the same watershed as a mining site or in an adjacent watershed, but sample points were $\geq 135 \mathrm{~m}$ from mine edge and shared no more than one edge with MTMVF areas.

Fig. 2. Geographic extent of bituminous coal bed (dark gray) and Bird Conservation Region 28 (BCR 28; light gray). Coal bed region and BCR 28 overlap approximately $40 \%$ within the Appalachian region of the eastern United States.

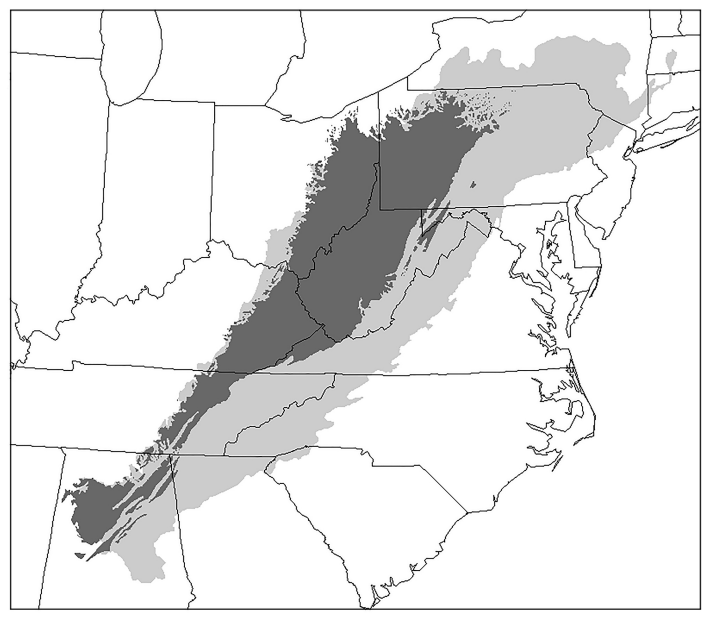

Fig. 3. Treatments used to assess songbird community response to mountaintop mining/valley fill in the central Appalachian region. Photos of treatments show typical habitat at the study site: reclaimed grassland (A), reclaimed shrubland (B), remnant forest (C), and intact forest (D).
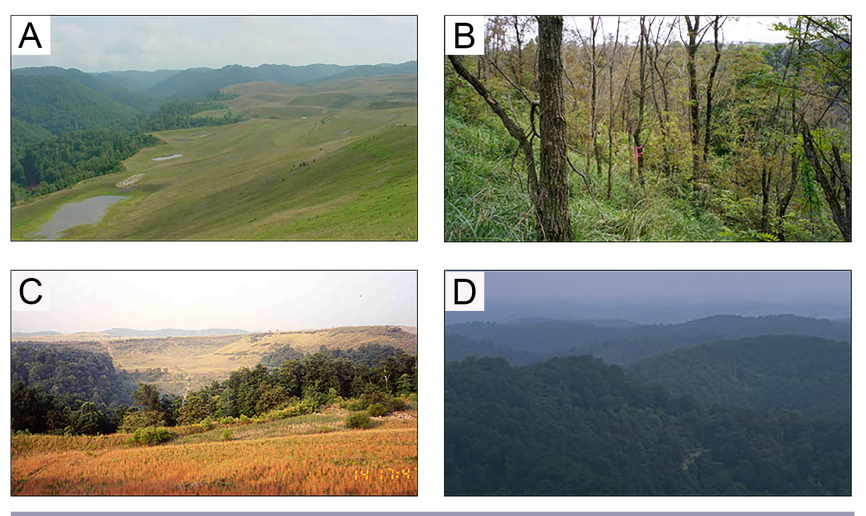

Sampling points were distributed systematically throughout each treatment type to sample available aspects, elevations, and slope positions. Points were placed $\geq 75 \mathrm{~m}$ from the edge of any other treatment and $\geq 250 \mathrm{~m}$ apart. In 1999, 96 points across the 4 treatments were sampled: 30 in reclaimed grassland, 6 in reclaimed shrubland, 24 in remnant forest, and 36 in intact forest. In 2000, 156 points across the 4 treatments were sampled, i.e., 40 in reclaimed grassland, 33 in reclaimed shrubland, 36 in remnant forest, and 47 in intact forest, with some points from 1999 not resurveyed in 2000 because of additional disturbance or access restrictions.

We quantified songbird abundance using standard 50-m fixed radius, 10-min point counts (Ralph et al. 1993) from 0630 to 1030 h during late May to June of 1999 and 2000. All birds seen or heard in a 10-min period were recorded. We recorded whether the bird was observed visually or aurally, identified sex when possible, recorded whether it was flying over, and recorded whether it was within or outside the $50-\mathrm{m}$ plot. Surveys were not conducted during windy or rainy weather. All points were surveyed twice each year, each time by a different observer. Two observers conducted all counts in 1999, and the same 2 observers plus a third person conducted all counts in 2000. All observers had previous experience identifying songbird species by sight and sound. Prior to initiating surveys, observers conducted simultaneous point counts to practice and verify bird identification skills and distance estimation.

We measured vegetation at all point count locations using methods modified from James and Shugart (1970) and the Breeding Bird Research Database program (Martin et al. 1997). We measured variables on 4 subplots (11.3-m radius or 0.04 ha each, and 5-m radius) at each point count location, with 1 subplot centered on the point count and 3 subplots $35 \mathrm{~m}$ from the center spaced $120^{\circ}$ apart $\left(0^{\circ}, 120^{\circ}\right.$, and $\left.240^{\circ}\right)$. Within each 0.04 -ha subplot, we recorded trees $>8 \mathrm{~cm}$ DBH. To quantify tree stem density, we counted the number of woody stems within each $0.04-$ ha subplot and grouped them into 1 of $2 \mathrm{DBH}$ classes: $>8-38 \mathrm{~cm}$ and $>38 \mathrm{~cm}$ DBH. Within a $5 \mathrm{~m}$ radius subplot, we counted the number of sapling stems (woody species $>0.5 \mathrm{~m}$ high) and placed 
Table 1. Mean and standard error (SE) of habitat variables in each treatment type. A one-way analysis of variance with a WallerDuncan $k$ ratio $t$ test was used to test for significant differences among treatment types. Superscripted letters indicate significant differences at the $\alpha=0.05$ level.

\begin{tabular}{|c|c|c|c|c|c|c|c|}
\hline \multirow[b]{2}{*}{ Variables } & \multirow{2}{*}{$\frac{\text { Reclaimed Grassland }}{\text { Mean } \pm \text { SE }}$} & \multirow{2}{*}{$\frac{\text { Reclaimed Shrubland }}{\text { Mean } \pm \text { SE }}$} & \multirow{2}{*}{$\begin{array}{c}\text { Remnant Forest } \\
\text { Mean } \pm \text { SE }\end{array}$} & \multirow{2}{*}{$\begin{array}{c}\text { Intact Forest } \\
\text { Mean } \pm \text { SE }\end{array}$} & \multicolumn{3}{|c|}{ Waller-Duncan } \\
\hline & & & & & $F$ & $\mathrm{df}$ & $p$ \\
\hline$\overline{\text { Slope }(\%)^{\dagger}}$ & $16.96 \pm 2.10^{\mathrm{B}}$ & $10.16 \pm 1.93^{\mathrm{C}}$ & $33.78 \pm 2.28^{\mathrm{A}}$ & $33.75 \pm 2.07^{\mathrm{A}}$ & 42.95 & 3 & $<0.001$ \\
\hline Aspect code ${ }^{\dagger}$ & $1.05 \pm 0.10$ & $0.77 \pm 0.11$ & $1.05 \pm 0.12$ & $1.03 \pm 0.08$ & 1.86 & 3 & 0.14 \\
\hline Elevation $(\mathrm{m})^{\dagger}$ & $400.27 \pm 7.47^{\mathrm{A}}$ & $378.85 \pm 11.53^{\mathrm{B}}$ & $332.08 \pm 7.11^{\mathrm{C}}$ & $399.47 \pm 11.24^{\mathrm{A}}$ & 24.94 & 3 & $<0.001$ \\
\hline Distance to major edge $(\mathrm{m})$ & $347.35 \pm 44.30^{\mathrm{B}}$ & $253.98 \pm 34.46^{\mathrm{C}}$ & $128.61 \pm 12.52^{\mathrm{D}}$ & $1430.66 \pm 145.32^{\mathrm{A}}$ & 537.85 & 3 & $<0.001$ \\
\hline Robel pole index & $2.93 \pm 0.17^{\mathrm{B}}$ & $4.30 \pm 0.27^{\mathrm{A}}$ & & $\bar{\ddagger}$ & 20.66 & 1 & $<0.001$ \\
\hline Canopy height (m) & $\ddagger$ & $4.68 \pm 0.46^{\mathrm{B}}$ & $21.77 \pm 0.73^{\mathrm{A}}$ & $22.98 \pm 0.67^{\mathrm{A}}$ & 222.63 & 2 & $<0.001$ \\
\hline Structural diversity index & $\ddagger$ & $3.85 \pm 0.29^{\mathrm{B}}$ & $11.58 \pm 0.23^{\mathrm{A}}$ & $11.37 \pm 0.22^{\mathrm{A}}$ & 262.81 & 2 & $<0.001$ \\
\hline \multicolumn{8}{|l|}{ Stem classes (stems/ha) } \\
\hline$<2.5 \mathrm{~cm}$ & $777.70 \pm 207.52^{\mathrm{B}}$ & $7475.38 \pm 1646.08^{\mathrm{A}}$ & $4935.76 \pm 450.55^{\mathrm{A}}$ & $6135.84 \pm 702.59^{\mathrm{A}}$ & 67.03 & 3 & $<0.001$ \\
\hline$\geq 2.5-8 \mathrm{~cm}$ & $73.15 \pm 18.79^{\mathrm{C}}$ & $979.17 \pm 292.52^{\mathrm{A}}$ & $901.04 \pm 65.86^{\mathrm{A}}$ & $587.37 \pm 55.71^{\mathrm{B}}$ & 79.55 & 3 & $<0.001$ \\
\hline$>8-38 \mathrm{~cm}$ & $0.03 \pm 0.02^{\mathrm{C}}$ & $132.58 \pm 23.72^{\mathrm{B}}$ & $429.17 \pm 35.26^{\mathrm{A}}$ & $352.93 \pm 12.90^{\mathrm{A}}$ & 565.54 & 3 & $<0.001$ \\
\hline$>38 \mathrm{~cm}$ & $0.00 \pm 0.00^{\mathrm{B}}$ & $0.00 \pm 0.00^{\mathrm{B}}$ & $44.27 \pm 3.77^{\mathrm{A}}$ & $42.35 \pm 3.17^{\mathrm{A}}$ & 993.28 & 3 & $<0.001$ \\
\hline Green ground cover $(\%)$ & $82.78 \pm 2.00^{\mathrm{B}}$ & $85.86 \pm 3.47^{\mathrm{A}}$ & $30.35 \pm 1.74^{\mathrm{C}}$ & $36.61 \pm 1.99^{C}$ & 130.34 & 3 & $<0.001$ \\
\hline Forb & $23.63 \pm 2.39$ & $21.89 \pm 2.86$ & $\ddagger$ & 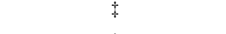 & 0.07 & 1 & 0.79 \\
\hline Grass & $45.05 \pm 2.71$ & $43.70 \pm 5.26$ & * & $\$$ & 0.15 & 1 & 0.70 \\
\hline Shrub & $14.13 \pm 2.72$ & $22.99 \pm 3.23$ & * & * & 3.54 & 1 & 0.06 \\
\hline
\end{tabular}

'Landscape-level variables used to estimate focal species' abundances (Table 3).

No data present for variable in that treatment.

them into 1 of 2 size classes: $<2.5 \mathrm{~cm}$ diameter at $10 \mathrm{~cm}$ aboveground and $\geq 2.5-8 \mathrm{~cm}$ diameter at $10 \mathrm{~cm}$ aboveground. Additional variables collected were slope percent (hereafter termed slope), aspect, elevation (m), distance to nearest major edge (m), a Robel pole index (Robel et al. 1970), canopy height (m), canopy cover, stem density, and percent ground cover of forbs, grasses, and shrubs. We measured slope and canopy height using a clinometer and transformed slope using the arcsine square root transformation (Zar 1999) prior to analyses. We measured aspect using a compass and transformed values using the Beers transformation (Beers et al. 1966) before analyses, where northeastern facing slopes receive a value of 2 and reflect high productivity and mesic conditions, whereas southwestern exposures receive a value of 0 and reflect xeric conditions, with all other exposures distributed between these values. We evaluated elevation using digital elevation models in ArcView GIS. We measured distance to major edge, represented by considerable breaks in contiguous habitat, from aerial photographs, where intact and remnant forest edges included valley fills and grasslands in mined areas, and grassland and shrubland edges were primarily forests. We measured total green ground cover using an ocular sighting tube (James and Shugart 1970) in all treatments and separated cover type into forb, grass, and shrub for reclaimed grasslands and shrublands. We quantified vegetation cover complexity using a Robel pole in reclaimed grasslands and shrublands. Structural diversity index measured the amount of canopy cover of different layers $(0.5-3 \mathrm{~m},>3-6$ $\mathrm{m},>6-12 \mathrm{~m},>12-18 \mathrm{~m},>18-24 \mathrm{~m}$, and $>24 \mathrm{~m}$ ) and the number of layers present (Nichols 1996). Canopy height and structural diversity index were not measured in reclaimed grasslands.

\section{Analyses}

\section{Habitat characteristics}

We compared the 16 topographic and vegetative characteristics (Table 1) among treatment types with one-way analysis of variance (ANOVA) tests. We used ANOVA because it is robust to conditions of nonnormality (Zar 1999) and robust to moderate departures from homogeneity of variance (Dowdy et al. 2004). By examining probability plots, we found that residuals of the raw data did not deviate excessively from normality. When ANOVAs indicated significant differences among treatment types, we used Waller-Duncan $k$ ratio $t$ tests to determine which treatment types differed. Variables were deemed significantly different at $\alpha=0.05$ and are reported as mean \pm standard error unless otherwise stated.

\section{Bird community-level patterns}

We used 50 m radius point count data from 1999 and 2000 to assess community-level patterns in avian richness and abundance. We excluded species that are not sampled well using point counts, i.e., flocking species, species with large territories, and nonvocal species, as well as all flyovers regardless of species for analyses, but we retained all other detection types, e.g., visual and auditory (song and call). We placed detected species into five habitat guilds (grassland, shrubland, interior edge, forest interior, and synanthropic; Appendix 1) a priori based on breeding biology of regional bird species (Ehrlich et al. 1988) and previous studies from the region (Whitcomb et al. 1981, O'Connell et al. 2000, McDermott and Wood 2009, Thomas et al. 2014, Farwell et al. 2016). Grassland guild species are associated with grasslands or prairies, shrubland guild species are associated with shrub/scrub or recently disturbed habitats, interior-edge guild birds are species commonly found in mature forests but that are tolerant of forest edges, forest interior guild birds are species that are associated with large tracts of core mature forest, and synanthropic guild birds are species that show a symbiotic relationship with humans.

We calculated guild richness as the cumulative number of species detected across both surveys each year at each point count station. For points surveyed in both years, we used the mean richness from the two years to account for unequal sampling effort among points and treatments. We compared richness of each guild across the 
Table 2. Site-level a priori candidate models tested for each species (top section) and resulting species best-fit model (lower section) to estimate abundances of focal species (see Table 3 for abundance estimates) using a single-season binomial $N$-mixture model. Treatment was included as a site-level covariate in all models. Other site-level covariates (slope, aspect, and elevation) were considered nuisance variables that helped explain patterns in abundance, independent of "treatment." Surveylevel covariates $(p)$ included "observer" and "time since sunrise" for all candidate models. See Table 3 for scientific names of species.

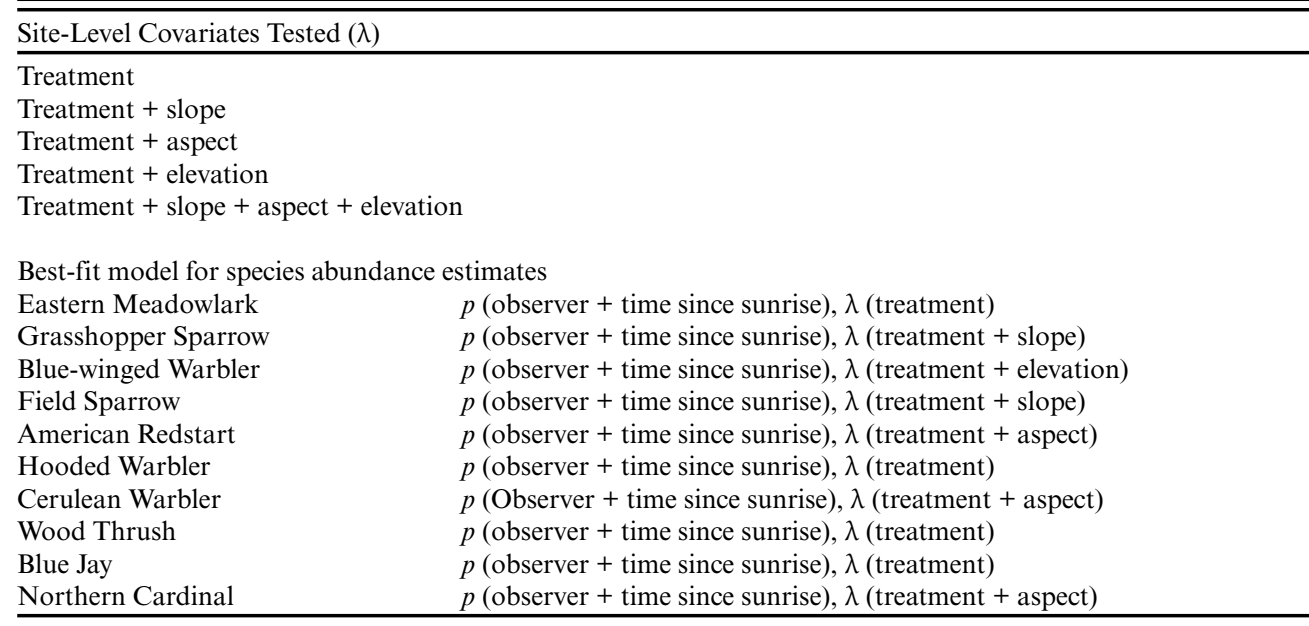

four treatments using one-way ANOVAs, followed with WallerDuncan $k$ ratio $t$ tests when ANOVAs were significant. Guild richness was deemed significantly different at $\alpha=0.05$ and was reported as mean \pm standard error unless otherwise stated.

We used redundancy analysis (RDA) to determine if there was a community-level effect of treatment type and to visualize species associations with treatments. Species that had $\geq 5$ total occurrences over the study period were included in RDA; thus 58 of 90 detected species were included in the analysis (Appendix 1). For the analysis, we used the number of detections per visit for each species averaged across all visits because of uneven sampling effort across our study. We transformed the count data using the "Hellinger" method to remove the influence of double zeros (Legendre and Gallagher 2001). We performed a detrended correspondence analysis on the transformed data to ensure the gradient length was $<4$ (gradient length $=3.18$ ), and thus species responses to the environmental gradient could be fit with a linear model (Lepš and Šmilauer 2003, Legendre and Legendre 2012). We used a correlation matrix, which gives equal weight to all species (Legendre and Legendre 2012). We visually assessed species-level associations using a distance biplot, where angles between the species data and treatment types reflect their correlations, and Euclidean distance reflects the differences among treatment types (Borcard et al. 2011). We performed the RDA using the software package vegan (version 2.3-4; Oksanen et al. 2016) in program $R$ ( $R$ Core Team 2016).

\section{Bird focal-species abundances}

To examine the influence of site- and survey-specific covariates on abundance, we evaluated five a priori models (Table 2) for each of two focal species from each of the five guilds represented within our study area (Table 2, Appendix 1). Nonsynanthropic species were chosen based on their high assessment scores for conservation need (Rosenberg et al. 2016; Appendix 1). We used a single-season binomial $N$-mixture model to account for imperfect detectability associated with point count surveys (Royle 2004). Site covariates included treatment, i.e., intact forest, remnant forest, reclaimed shrubland, and reclaimed grassland, as our primary variable of interest, and slope, Beers aspect, and elevation because these topographic variables can affect avian species presence and abundance and were varied across survey points. Survey covariates, observer and time since sunrise, were included in all models. Because species with low detections in certain treatments, e.g., Grasshopper Sparrows (Ammodramus savannarum) in intact and remnant forests, caused nonconvergence in models, we restricted analyses to treatments with sufficient detections to satisfy convergence for models. We used a second-order information criterion $\left(\mathrm{AIC}_{\mathrm{c}}\right.$ ) to account for small sample size and selected a best model (lowest $\mathrm{AIC}_{\mathrm{c}}$ ) from all candidate models using an information theoretic approach (Burnham and Anderson 2002). The global model for each species was tested for overdispersion (c-hat $\geq 1$ ) using a goodness-of-fit test with $\alpha=0.05$ and subsequently accounted for in our treatment-level best-fit model abundance estimates by inflating the $95 \%$ confidence intervals based on global model c-hat values (Kéry and Royle 2016).

We used $50 \mathrm{~m}$ radius point count data from 1999 and 2000 and only included singing or visual detections of males for analysis. Abundances were estimated at the "birds per point" level for each treatment type, with all other site-specific covariates set at their mean values. We chose single-season rather than multiseason models because number of survey replicates was low, some points were only surveyed 1 year, and we were interested in estimating abundance differences of songbirds among treatments rather than changes between years. Thus, each point contributed either 2 or 
Table 3. Mean abundance estimates derived from the best-supported single-season binomial $N$-mixture model from species-specific analysis at the "per point" level ( $95 \%$ confidence intervals) in each treatment.

\begin{tabular}{|c|c|c|c|c|}
\hline & \multicolumn{4}{|c|}{ Treatment Type } \\
\hline & $\begin{array}{l}\text { Reclaimed } \\
\text { Grassland }\end{array}$ & $\begin{array}{l}\text { Reclaimed } \\
\text { Shrubland }\end{array}$ & Remnant Forest & Intact Forest \\
\hline \multicolumn{5}{|l|}{ Grassland species } \\
\hline Eastern Meadowlark (Sturnella magna) & $0.99(0.41-2.40)$ & $0.14(0.02-0.79)$ & $\dagger$ & $\dagger$ \\
\hline Grasshopper Sparrow (Ammodramus savannarum) & $5.80(2.39-13.98)$ & $0.58(0.23-1.47)$ & $\dagger$ & $\dagger$ \\
\hline \multicolumn{5}{|l|}{ Shrubland species } \\
\hline Blue-winged Warbler (Vermivora cyanoptera) & $0.95(0.39-2.33)$ & $3.06(1.33-7.05)$ & $0.20(0.07-0.58)$ & $0.17(0.05-0.55)$ \\
\hline Field Sparrow (Spizella pusilla) & $1.39(0.70-2.75)$ & $2.69(1.34-5.38)$ & 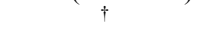 & \\
\hline \multicolumn{5}{|l|}{ Interior-edge species } \\
\hline American Redstart (Setophaga ruticilla) & ${ }^{\dagger}$ & $0.24(0.07-0.84)$ & $0.53(0.22-1.18)$ & $1.53(0.80-2.91)$ \\
\hline Hooded Warbler (Setophaga citrina) & $0.06(0.01-0.56)$ & $0.27(0.06-1.19)$ & $0.55(0.17-1.71)$ & $1.67(0.61-4.55)$ \\
\hline \multicolumn{5}{|l|}{ Forest interior species } \\
\hline Cerulean Warbler (Setophaga cerulea) & $0.10(0.02-0.47)$ & $\dagger$ & $1.18(0.45-3.11)$ & $1.84(0.71-4.78)$ \\
\hline Wood Thrush (Hylocichla mustelina) & $0.20(0.03-1.45)$ & ${ }^{\dagger}$ & $3.16(0.74-13.39)$ & $3.14(0.74-13.26)$ \\
\hline \multicolumn{5}{|l|}{ Synanthropic species } \\
\hline Blue Jay (Cyanocitta cristata) & $0.56(0.07-4.71)$ & $3.82(0.47-30.96)$ & $2.91(0.35-24.12)$ & $3.74(0.53-26.19)$ \\
\hline Northern Cardinal (Cardinalis cardinalis) & $0.86(0.45-1.67)$ & $2.48(1.26-4.88)$ & $1.16(0.54-2.44)$ & $0.59(0.29-1.22)$ \\
\hline
\end{tabular}

4 survey replicates to estimation of model parameter values. Single-season models do assume closure during the sampling period, and thus the variability in counts is caused by imperfect detection rather than changes in abundance. To assess if major changes in focal species abundances likely occurred at survey points between years, we conducted paired $t$ tests using maximum single-visit detections each year. Only 1 of 10 focal species, i.e., Blue-winged Warbler (Vermivora cyanoptera), showed a significant difference in number of detected males between years. Thus, overall our focal species populations appeared to be stable during the sampling period, and our single-season models should not be heavily biased by violation of closure. $N$-mixture model analyses were conducted using the packages unmarked (Fiske and Chandler 2011), AHMbook (Kéry and Royle 2016), and AICcmodavg (Mazerolle 2016) in program R ( $\mathrm{R}$ Core Team 2016). We then used the top model for each species as determined by $\mathrm{N}$-mixture model selection (Table 2 ) to generate modeled abundance corrected for detection and to assess songbird abundance differences among treatment type (Table 3).

\section{RESULTS}

\section{Habitat characteristics}

Vegetation variable differences were generally split into forested treatments (remnant and intact forest) and nonforested reclaimed treatments (grasslands and shrublands). Forested treatments had greater structural diversity and canopy height than reclaimed shrublands; canopy height and structural diversity were not measured in reclaimed grasslands. Total green ground cover was significantly higher in reclaimed treatments $(84 \%)$ than in forested treatments $(33 \%)$. Stem densities of trees $>8 \mathrm{~cm} \mathrm{DBH}$, i.e., $>8-38$ $\mathrm{cm}$ and $>38 \mathrm{~cm} \mathrm{DBH}$, were significantly greater in forested treatments than reclaimed treatments, whereas woody stems $\leq 8$ $\mathrm{cm}$ DBH showed no clear distinction between forested and reclaimed treatments. Slope was significantly greater, i.e., steeper, in forested treatments than reclaimed treatments, whereas other landscape variables, i.e., distance to major edge and elevation, were significantly different among treatments but showed no clear separation between forested and reclaimed treatments.

Habitat variables measured in remnant and intact forests were generally similar (Table 1). Only one vegetation variable differed, with a greater number of stems $>2.5-8 \mathrm{~cm} \mathrm{DBH}$ in remnant forest. Distance to major edge (1430 $\mathrm{m}$ and $128 \mathrm{~m}$ in intact forest and remnant forest, respectively) and elevation (399 $\mathrm{m}$ and $332 \mathrm{~m}$ for intact forest and remnant forest, respectively) differed significantly, although actual elevation values were not substantially different.

Many vegetative variables measured in reclaimed grasslands and shrublands were significantly different between treatments, e.g., slope, elevation, distance to major edge, Robel pole index, stem density, and green ground cover, with stem density being the most notable (Table 1). Reclaimed shrublands had significantly higher stem densities in $<2.5 \mathrm{~cm}, \geq 2.5-8 \mathrm{~cm}$, and $>8-38 \mathrm{~cm}$ classes than reclaimed grasslands, and reclaimed shrublands had a significantly higher Robel pole index. Total green ground cover was significantly different between these two treatments $(83 \%$ and $86 \%$ in grasslands and shrublands, respectively), whereas forb, grass, and shrub ground cover did not differ.

\section{Bird community-level patterns}

Bird guild richness was significantly different across treatment types for each guild: grassland, $F_{3,158}=138.0, p<0.001$; shrubland, $F_{3,158}=208.1, p<0.001$; interior edge, $F_{3}=73.9, p<$ 0.001 ; forest interior, $F_{3,158}=144.1, p<0.001$; and synanthropic, $F_{3,158}=5.3, p<0.001$. Guild richness generally followed expected patterns of habitat associations (Fig. 4). Grassland bird guild richness was greatest in reclaimed grasslands. Shrubland and synanthropic guilds had greatest richness in reclaimed shrublands. Richness for interior-edge species was greatest in both intact forests and remnant forests. In contrast, forest interior bird guild richness was greatest in intact forests. Reclaimed shrublands had greatest overall species richness because all guilds except forest interior contributed high or moderate richness. 
Fig. 4. Species richness of five bird guilds in four central Appalachian mountaintop mining/valley fill treatments. Letters notate significant differences within each guild across treatment types at $p=0.05$, with mean and standard error shown.

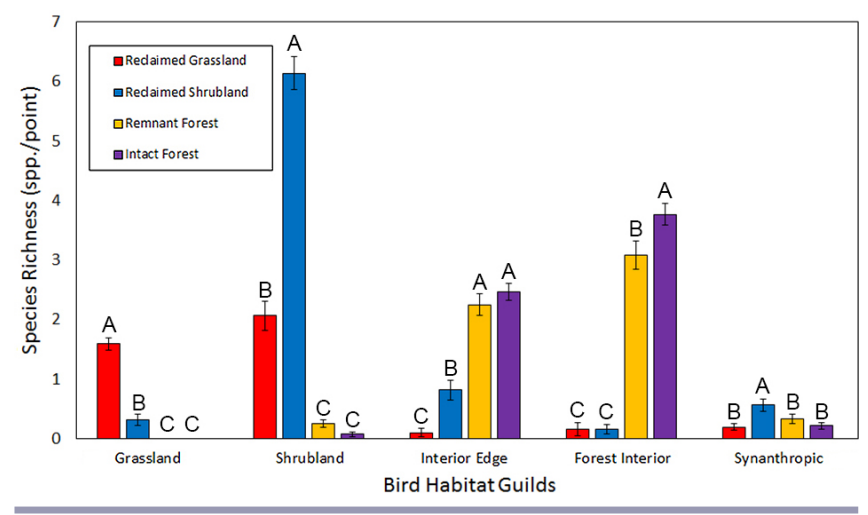

The RDA based on detections within a 50-m radius also indicated species-habitat associations were nonrandom $\left(F_{3,7}=4.2, p<\right.$ 0.001 ). We found that $23 \%$ of the variance was explained by treatment type. All forest interior species except one, Hairy Woodpecker (Picoides villosus), were tightly grouped with intact forest, as were many interior-edge species (Fig. 5). Forest treatments were distinctly different from grassland and shrubland treatments, indicated by spatial separation of treatment labels in Figure 5.

\section{Bird focal-species abundances}

Focal species abundances were estimated using the best-fit model (Table 2). Songbird species modeled abundances were highest in their respective a priori guild groupings and mirrored trends in guild richness (Table 3 ). Grassland and shrubland species had highest abundance estimates in treatments that had been reclaimed (grasslands and shrublands) versus treatments that remained forested (Table 3). Grasshopper Sparrows (scientific names in Table 3) had noteworthy high abundance in reclaimed grasslands. Species in interior-edge and forest interior guilds had the highest abundance estimates in treatments that had not been mined and reclaimed (remnant and intact forest). Three of the four forest-associated species analyzed, i.e., American Redstart (Setophaga ruticilla), Cerulean Warbler, and Hooded Warbler (Setophaga citrina), had higher abundance estimates in intact forests than remnant forests. Species in the synanthropic guild were relatively common across all treatments, with abundance being highest in reclaimed shrubland (Table 3 ).

\section{DISCUSSION}

Mined lands reclaimed with the traditional grassland approach supported fewer species (Figs. 4 and 5) and lower estimated abundances of focal species (Table 3) than reclaimed shrubland, remnant forest, and intact forest for all but the grassland songbird guild. Although reclaimed shrublands on our study areas were not a result of applying the forest reclamation approach guidelines (Adams 2017), they still supported higher abundance and richness of songbirds typically associated with early successional or young forests in the central Appalachian region. This supports the notion that the forest reclamation approach, where trees are
Fig. 5. Distance biplot showing species-habitat associations in four central Appalachian mountaintop mining/valley fill treatment types: reclaimed grassland (GR), reclaimed shrubland (SH), remnant forest (RF), and intact forest (IN). Species alpha codes are provided in Appendix 1 and are colored according to their habitat guild: grassland (black), shrubland (purple), interior edge (red), forest interior (blue), and synanthropic (green). Spatial locations of species alpha codes indicate degree of similarity to treatment type. Inset box shows tight clustering of forest species with IN and RF. RDA, redundancy analysis.

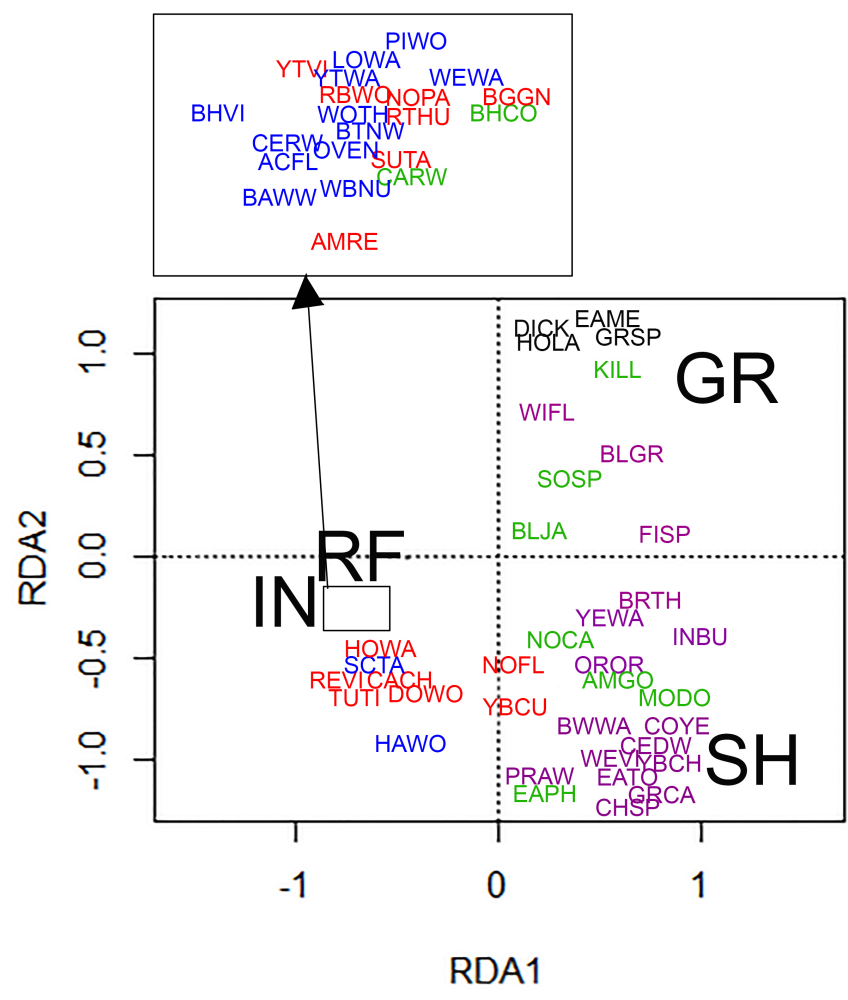

planted with the goal of creating young forest areas immediately and expediting forest succession, would benefit shrubland and forest-associated songbirds.

Our study corroborated our hypothesis that the bird community differed between reclaimed MTMVF complexes and adjacent unmined forests in southwestern West Virginia. These results justify further examination into the mine reclamation process in the central Appalachian region and the trade-offs associated with grassland and forest mine reclamation techniques. Analysis of the bird community indicates reclaimed grasslands on MTMVF complexes were used by grassland songbirds and a few shrubland species. Reclaimed grasslands were characterized by dense ground cover with no canopy present and yielded the lowest total species richness of all treatments. Despite low species richness of grassland species compared with other guilds, mining complexes were used by grassland birds in our study and others (DeVault et al. 2002, Scott and Lima 2004). Grasshopper Sparrows, in particular, had high abundance on our sites (Table 3). Grassland songbirds have been declining throughout much of North 
America (Ribic et al. 2009), and mines reclaimed with grasslands provide habitat for this group of species, although grassland species are naturally rare in the central Appalachians (Wood and Ammer 2015). Forest-associated songbirds (interior-edge and forest interior species) occurred in low numbers in reclaimed grasslands and shrublands, suggesting MTMVF complexes were suboptimal for forest birds. We also provided evidence of forestdwelling bird displacement on MTMVF complexes, particularly area-sensitive species, which has rarely been reported (Weakland and Wood 2005, Wood et al. 2006). Forest-associated species were linked with remnant and intact forest, though more strongly with intact forest, showing their preference toward forested areas in a mining matrix landscape.

Grassland birds are habitat specialists, and some are area sensitive (Walk and Warner 1999, Johnson and Igl 2001); thus, large areas of reclaimed grasslands may prove important for this group of birds (Stauffer et al. 2011). When surface mines are reclaimed using the grassland approach, they are often in an arrested state of succession because of the compaction and acidity of soils. Studies have reported grassland birds using these areas 20 years after mine reclamation (DeVault et al. 2002, Ingold and Dooley 2013, Borthwick and Wang 2015, Wood and Ammer 2015), and this was evident in our study, where grassland species were present 19 years after mine reclamation. Despite reclaimed mines providing long-term habitat for grassland birds, quality can decline over time leading to reduced nesting productivity (Wood and Ammer 2015). This degradation in reclaimed grasslands over time may result from nonnative grasses being predominant in these areas (Scott and Lima 2004), which reduce insect production and create poor breeding conditions (Galligan et al. 2006). Grasslands on reclaimed mines differ from native prairies in that plant diversity is low on mines with few native species present (Scott et al. 2002), and reclaimed mines often are dominated by species that are adapted to infertile soils, e.g., tall fescue and smooth brome (Bromus inermis; Brothers 1990, Wood and Ammer 2015). Further research is needed comparing native and nonnative plant reclamation on surface mines and how this may affect long-term plant composition and reproductive benefits for songbirds. Additionally, grasslands are not historically prominent within the central Appalachians (Hall 1983) and are mainly a byproduct of surface mining (Townsend et al. 2009) or land conversion for agriculture.

Reclaimed shrublands in our study were generally a product of the grassland reclamation approach, but with additional woody plantings and some natural regeneration of woody species. Reclaimed shrublands provided a large array of vegetative conditions on mines, with the highest stem densities in the $<2.5$ $\mathrm{cm}$ and $\geq 2.5-8 \mathrm{~cm}$ DBH classes, the highest percentage of total ground cover, and some overstory cover and vegetative structure (Table 1). The combination of understory vegetation mixed with partial canopy cover created characteristics suitable for a wide variety of birds, e.g., reclaimed shrubland contained the highest species richness for shrubland and synanthropic guilds and second-highest for interior edge (Fig. 4). Although shrubland birds have been understudied on reclaimed surface mines (Bulluck and Buehler 2006), they made up a large portion of the overall bird community in our study (16 of 58 species, the most species for a single guild; Appendix 1). Because habitat use does not always equal habitat suitability (Van Horne and Wiens 1991), comparisons of reproductive success of shrubland songbird species in the grassland and forest reclamation approaches is needed. Because woody encroachment onto grasslands will likely push grassland birds off of surface mines (Graves et al. 2010, Hill and Diefenbach 2013), Graves et al. (2010) suggested that grasslands be maintained as grasslands because of the improbability of reestablishment of a functioning forest ecosystem because of poor soil conditions. Although reclaimed shrublands provide important habitat to many shrubland and young forest species that have been declining throughout the Appalachian region (Schlossberg et al. 2010), the slow succession on mines reclaimed with grasses results in very few areas developing woody vegetation. If shrubland or young forest conditions are the desired future condition, then the forest reclamation approach may be a more suitable approach to more quickly develop woody vegetation postreclamation (Zipper et al. 2011, McDermott et al. 2013, Wood et al. 2013).

Remnant and intact forest shared many vegetation characteristics and supported similar avian species composition (Fig. 5), but intact forests supported greater richness of forest interior species (Fig. 4), and 3 of 4 forest-dependent focal species had higher estimated abundances in intact forests (Table 3). Both of the forest treatments were characterized by greater canopy height and greater number of large diameter trees $(8-38 \mathrm{~cm}$ and $>38 \mathrm{~cm} \mathrm{DBH}$ classes) compared with reclaimed grassland and shrubland (Table 1), which contributed to the lower abundances and guild richness of forest species on mine complexes. Intact forest was associated with core forested areas, and sample points were located farther from nonforested edges compared with remnant forest. Thus, lower abundance of area-sensitive forest species in MTMVF complexes may also result from the fragmentation or complete loss of core forest (Becker et al. 2015, Farwell et al. 2016), likely because of reduced amounts of intact forest and increased edge. Reclaiming mines using a forest approach may lessen the impacts from mining on the forest bird community by quickly developing young forest and shrubland, which softens habitat edges and increases forest core area (McDermott et al. 2013). However, because the forest reclamation approach has been implemented only in recent years and on small acreages, no studies have examined avian response on mined lands reclaimed using the forest reclamation approach.

Revegetation techniques on surface mines have long-term effects on habitat suitability for birds and other wildlife because of slow successional processes (Evans et al. 2013). Traditional reclamation practices encouraged mining companies to primarily reclaim mines with grasses (Zipper et al. 2011), which addressed the need to reduce soil erosion, sedimentation, landslides, and instability. This approach typically slows the successional processes of woody plants, reducing the likelihood of returning these areas to native forests and subsequently the return of forest birds. Although the forest approach is relatively new compared with the traditional grassland approach, some studies have reported faster establishment of woody plants and higher growth rates of tree species when using the forest reclamation approach (Burger and Zipper 2011, Evans et al. 2013). The forest approach could benefit many young forest bird species by creating dense patches of native shrubs with sapling and herbaceous cover (Bakermans et al. 2009, Wood et al. 2013). Although no forest approach sites are old enough to have developed into mature 
forest, we would expect the forest reclamation approach to increase the likelihood of forest bird return to MTMVF complexes and not just to the complexes' peripheral forests (Burger and Zipper 2011, McDermott et al. 2013).

In summary, surface mines reclaimed with grasses support grassland birds, but benefits may deteriorate over time (Wood and Ammer 2015). Concurrently, forest birds, particularly areasensitive or conservation concern species, are adversely affected by mines reclaimed with grasses based on species abundances and guild richness from our study. Ultimately, there are winners and losers associated with the decision to reclaim mines with either grasses or trees. Both bird groups have seen declining populations throughout North American (Askins et al. 2007, Sauer et al. 2014) in recent decades, but managing for both at a relatively small scale, e.g., mine landscapes ( 2500 ha in our study), may be difficult. In a region like the central Appalachians, where intact, mature forest is the predominant, native land cover and consequently an important focus for forest bird conservation, it is important that we understand ways of returning forests to these areas that have been highly subjected to disturbance. The Appalachian Mountains Joint Venture lists 9 land bird species as the highest conservation priority: Bewick's Wren (Thryomanes bewickii), Blue-winged Warbler, Cerulean Warbler, Golden-winged Warbler (Vermivora chrysoptera), Kentucky Warbler (Geothlypis formosa), Prairie Warbler (Setophaga discolor), Wood Thrush, Wormeating Warbler (Helmitheros vermivorum), and Henslow's Sparrow (Ammodramus henslowii). All but one, Henslow's Sparrow, are considered forest interior, interior-edge, or shrubland species. The Henslow's Sparrow is an obligate grassland species and considered rare in the central Appalachian region. Therefore, from an avian conservation standpoint, surface mine reclamation in the central Appalachians could focus on implementing a forest reclamation approach over a traditional grassland approach. Recovery of forest bird presence on mines reclaimed using the grassland approach is unknown, but it is postulated to be hundreds of years for functioning forests to develop (Zipper et al. 2011, Wickham et al. 2013).

Although songbird response to the forest reclamation approach has not been studied explicitly, the results from our reclaimed shrubland treatment suggest that shrubland birds would respond positively. Further, the grassland approach has proved to limit forest bird abundances in areas that previously supported forest communities. Because large areas in the Appalachian region have the potential for surface mining (Fig. 2), it is important to understand the trade-offs of reclaiming mined lands with a grassland or forest approach. A clearer understanding of best management practices for mine reforestation (Adams 2017) will help practitioners make sound management decisions that benefit birds, other wildlife, and whole ecosystems. Thus, further research on sites reclaimed with the forest approach and resampling of reclaimed sites older than those sampled in our study would provide valuable data to help determine effective management recommendations for mine reclamation in the future.

Responses to this article can be read online at: http://www.ace-eco.org/issues/responses.php/1304

\section{Acknowledgments:}

Research funding was provided by the U.S. Environmental Protection Agency, West Virginia State Legislature, and West Virginia Division of Natural Resources. This research was conducted under the approved IACUC protocol \#9904-10 at West Virginia University. The use of trade, firm, or product names is for description purposes only and does not imply endorsement by the U.S. Government. We thank J. Anderson, M. Balcerzak, and D. Chamblin for field assistance and two anonymous reviewers that provided helpful comments on an earlier draft.

\section{LITERATURE CITED}

Adams, M. B. 2017. The Forestry Reclamation Approach: guide to successful reforestation of mined lands. General Technical Report NRS-169. U.S. Forest Service Northern Research Station, Newtown Square, Pennsylvania, USA. http://dx.doi.org/10.2737/ NRS-GTR-169

Angel, P., V. Davis, J. Burger, D. Graves, and C. Zipper. 2005. The Appalachian Regional Reforestation Initiative. Forest Reclamation Advisory No. 1. U.S. Department of Interior, Office of Surface Mining Reclamation and Enforcement, Washington, D.C., USA.

Askins, R. A., F. Chávez-Ramírez, B. C. Dale, C. A. Haas, J. R. Herkert, F. L. Knopf, and P. D. Vickery. 2007. Conservation of grassland birds in North America: understanding ecological processes in different regions. Ornithological Monographs 64: iii-46. http://dx.doi.org/10.2307/40166905

Bakermans, M. H., J. L. Larkin, B. W. Smith, T. M. Fearer, and B. C. Jones. 2009. Golden-winged Warbler habitat best management practices for forestlands in Maryland and Pennsylvania. American Bird Conservancy, The Plains, Virginia.

Becker, D. A., P. B. Wood, M. P. Strager, and C. Mazzarella. 2015. Impacts of mountaintop mining on terrestrial ecosystem integrity: identifying landscape thresholds for avian species in the central Appalachians, United States. Landscape Ecology 30:339-356. http://dx.doi.org/10.1007/s10980-014-0134-8

Beers, T. W., P. E. Dress, and L. C. Wensel. 1966. Notes and observations: aspect transformation in site productivity research. Journal of Forestry 64:691-692.

Borcard, D., F. Gillet, and P. Legendre. 2011. Numerical ecology with $R$. Springer, New York, New York, USA. http://dx.doi. org/10.1007/978-1-4419-7976-6

Borthwick, R. R., and Y. Wang. 2015. Bird species' responses to post mine reclamation in Alabama - a preliminary analysis. Journal of the American Society of Mining and Reclamation 4:1-19.

Brothers, T. S. 1990. Surface-mine grasslands. Geographical Review 80:209-225. http://dx.doi.org/10.2307/215300

Bulluck, L. P., and D. A. Buehler. 2006. Avian use of early successional habitats: are regenerating forests, utility right-ofways and reclaimed surface mines the same? Forest Ecology and Management 236:76-84. http://dx.doi.org/10.1016/j.foreco.2006.08.337 
Burger, J. A., and C. E. Zipper. 2011. How to restore forests on surface-mined land. Virginia Cooperative Extension Publication 460-123. Virginia Cooperative Extension, Virginia Tech, Blacksburg, Virginia, USA.

Burnham, K. P., and D. R. Anderson. 2002. Model selection and multimodel inference: a practical information-theoretic approach. Second edition. Springer, New York, New York, USA.

Chaney, W. R., P. E. Pope, and W. R. Byrnes. 1995. Tree survival and growth on land reclaimed in accord with Public Law 95-87. Journal of Environmental Quality 24:630-634. http://dx.doi. org/10.2134/jeq1995.00472425002400040013x

Coppedge, B. R., D. M. Engle, S. D. Fuhlendorf, R. E. Masters, and M. S. Gregory. 2001. Landscape cover type and pattern dynamics in fragmented southern Great Plains grasslands, USA. Landscape Ecology 16:677-690. http://dx.doi.org/10.1023/ A:1014495526696

DeVault, T. L., P. E. Scott, R. A. Bajema, and S. L. Lima. 2002. Breeding bird communities of reclaimed coal-mine grasslands in the American Midwest. Journal of Field Ornithology 73:268-275. http://dx.doi.org/10.1648/0273-8570-73.3.268

Dowdy, S., S. Wearden, and D. Chilko. 2004. Statistics for research. Third edition. John Wiley and Sons, Hoboken, New Jersey, USA. http://dx.doi.org/10.1002/0471477435

Drummond, M. A., and T. R. Loveland. 2010. Land-use pressure and a transition to forest-cover loss in the eastern United States. BioScience 60:286-298. http://dx.doi.org/10.1525/bio.2010.60.4.7

Ehrlich, P. R., D. S. Dobkin, and D. Wheye. 1988. The birder's handbook: a field guide to the natural history of North American birds. Simon and Schuster, New York, New York, USA.

Evans, D. M., C. E. Zipper, J. A. Burger, B. D. Strahm, and A. M. Villamagna. 2013. Reforestation practice for enhancement of ecosystem services on a compacted surface mine: path towards ecosystem recovery. Ecological Engineering 51:16-23. http://dx. doi.org/10.1016/j.ecoleng.2012.12.065

Farwell, L. S., P. B. Wood, J. Sheehan, and G. A. George. 2016. Shale gas development effects on the songbird community in a central Appalachian forest. Biological Conservation 201:78-91. http://dx.doi.org/10.1016/j.biocon.2016.06.019

Fiske, I., and R. Chandler. 2011. unmarked: an R package for fitting hierarchical models of wildlife occurrence and abundance. Journal of Statistical Software 43:1-23. http://dx.doi. org/10.18637/jss.v043.i10

Galligan, E. W., T. L. DeVault, and S. L. Lima. 2006. Nesting success of grassland and savanna birds on reclaimed surface coal mines of the midwestern United States. Wilson Journal of Ornithology 118:537-546. http://dx.doi.org/10.1676/05-086.1

Grant, T. A., E. Madden, and G. B. Berkey. 2004. Tree and shrub invasion in northern mixed-grass prairie: implications for breeding grassland birds. Wildlife Society Bulletin 32:807-818. https://doi.org/10.2193/0091-7648(2004)032[0807:TASIIN]2.0.CO;2

Graves, B. M., A. D. Rodewald, and S. D. Hull. 2010. Influence of woody vegetation on grassland birds within reclaimed surface mines. Wilson Journal of Ornithology 122:646-654. http://dx.doi. org/10.1676/09-101.1
Hall, G. A. 1983. West Virginia birds: distribution and ecology. Special Publication of Carnegie Museum of Natural History No. 7. Carnegie Museum of Natural History, Pittsburgh, Pennsylvania, USA.

Hill, J. M., and D. R. Diefenbach. 2013. Experimental removal of woody vegetation does not increase nesting success or fledgling production in two grassland sparrows (Ammodramus) in Pennsylvania. Auk 130:764-773. http://dx.doi.org/10.1525/ auk.2013.12240

Ingold, D. J., and J. L. Dooley. 2013. Nesting success of grassland and shrub-nesting birds on The Wilds, an Ohio reclaimed surface mine. Ohio Journal of Science 111:37-41.

James, F. C., and H. H. Shugart, Jr. 1970. A quantitative method of habitat description. Audubon Field Notes 24:727-736.

Johnson, D. H., and L. D. Igl. 2001. Area requirements of grassland birds: a regional perspective. $A u k$ 118:24-34. http://dx. doi.org/10.1642/0004-8038(2001)118[0024:AROGBA]2.0.CO;2

Kéry, M., and J. A. Royle. 2016. Applied hierarchical modeling in ecology: analysis of distribution, abundance and species richness in $R$ and BUGS. Volume 1. Academic Press. London, UK.

Legendre, P., and E. D. Gallagher. 2001. Ecologically meaningful transformations for ordination of species data. Oecologia 129:271-280. http://dx.doi.org/10.1007/s004420100716

Legendre, P., and L. Legendre. 2012. Numerical ecology. Third edition. Elsevier, Oxford, UK.

Lepš, J., and P. Šmilauer. 2003. Multivariate analysis of ecological data using CANOCO. Cambridge University Press, New York, New York, USA. http://dx.doi.org/10.1017/CBO9780511615146

Martin, T. E., C. Paine, C. J. Conway, W. M. Hockachka, P. Allen, and W. Jenkins. 1997. BBIRD field protocol. Montana Cooperative Wildlife Research Unit, University of Montana, Missoula, Montana, USA.

Mazerolle, M. J. 2016. AICcmodavg: model selection and multimodel inference based on $(Q) A I C(c)$. $\mathrm{R}$ package version 2.0-4. R Foundation for Statistical Computing, Vienna, Austria. [online] URL: https://CRAN.R-project.org/package=AICcmodavg

McDermott, M. E., M. B. Shumar, and P. B. Wood. 2013. Case study: prioritization strategies for reforestation on minelands to benefit Cerulean Warblers. Journal of the American Society of Mining and Reclamation 2:80-98. http://dx.doi.org/10.21000/ JASMR13020080

McDermott, M. E., and P. B. Wood. 2009. Short- and long-term implications of clearcut and two-age silviculture for conservation of breeding forest birds in the central Appalachians, USA. Biological Conservation 142:212-220. http://dx.doi.org/10.1016/j. biocon.2008.10.016

Nichols, J. V. 1996. Effects of two-age timber management and clearcutting on songbird density and reproductive success. Thesis, West Virginia University, Morgantown, West Virginia, USA.

O'Connell, T. J., L. E. Jackson, and R. P. Brooks. 2000. Bird guilds as indicators of ecological condition in the central Appalachians. Ecological Applications 10:1706-1721. http://dx.doi.org/10.1890/1051-0761 (2000)010[1706:BGAIOE]2.0.CO;2 
Oksanen, J., F. G. Blanchet, R. Kindt, P. Legendre, P. R. Minchin, R. B. O'Hara, G. L. Simpson, P. Solymos, M. H. H. Stevens, and H. Wagner. 2016. vegan: community ecology package. $\mathrm{R}$ package version 2.3-3. R Foundation for Statistical Computing, Vienna, Austria. [online] URL: https://CRAN.R-project.org/package= vegan

Palmer, M. A., E. S. Bernhardt, W. H. Schlesinger, K. N. Eshleman, E. Foufoula-Georgiou, M. S. Hendryx, A. D. Lemly, G. E. Likens, O. L. Loucks, M. E. Power, P. S. White, and P. R. Wilcock. 2010. Mountaintop mining consequences. Science 327:148-149. http://dx.doi.org/10.1126/science.1180543

Ralph, C. J., G. R. Geupel, P. Pyle, T. E. Martin, and D. F. DeSante. 1993. Handbook of fieldmethods for monitoring landbirds. General Technical Report PSW-GTR-144. U.S. Forest Service, Pacific Southwest Research Station, Albany, California, USA. [online] URL: http://dx.doi.org/10.2737/PSW-GTR-144

R Core Team. 2016. R: A language and environment for statistical computing. R Foundation for Statistical Computing, Vienna, Austria. [online] URL: https://www.R-project.org/

Ribic, C. A., R. R. Koford, J. R. Herkert, D. H. Johnson, N. D. Niemuth, D. E. Naugle, K. K. Bakker, D. W. Sample, and R. B. Renfrew. 2009. Area sensitivity in North American grassland birds: patterns and processes. Auk 126:233-244. http://dx.doi. org/10.1525/auk.2009.1409

Robel, R. J., J. N. Briggs, A. D. Dayton, and L. C. Hulbert. 1970. Relationships between visual obstruction measurements and weight of grassland vegetation. Journal of Range Management 23:295-297. http://dx.doi.org/10.2307/3896225

Rosenberg, K. V., J. A. Kennedy, R. Dettmers, R. P. Ford, D. Reynolds, J. D. Alexander, C. J. Beardmore, P. J. Blancher, R. E. Bogart, G. S. Butcher, A. F. Camfield, A. Couturier, D. W. Demarest, W. E. Easton, J. J. Giocomo, R. H. Keller, A. E. Mini, A. O. Panjabi, D. N. Pashley, T. D. Rich, J. M. Ruth, H. Stabins, J. Stanton, and T. Will. 2016. Partners in Flight landbird conservation plan: 2016 revision for Canada and continental United States. Canadian Wildlife Service, Ottawa, Ontario, Canada.

Royle, J. A. 2004. $N$-mixture models for estimating population size from spatially replicated counts. Biometrics 60:108-115. http://dx.doi.org/10.1111/j.0006-341X.2004.00142.x

Sauer, J. R., J. E. Hines, J. E. Fallon, K. L. Pardieck, D. J. Ziolkowski, Jr., and W. A. Link. 2014. The North American Breeding Bird Survey, results and analysis 1966-2013. Version 01.30.2015. U.S. Geological Survey, Patuxent Wildlife Research Center, Laurel, Maryland, USA.

Sayler, K. L. 2008. Land cover trends: central Appalachians. U.S. Geological Survey, Reston, Virginia, USA. [online] URL: http:// landcovertrends.usgs.gov/east/eco69Report.html

Schlossberg, S., D. I. King, R. B. Chandler, and B. A. Mazzei. 2010. Regional synthesis of habitat relationships in shrubland birds. Journal of Wildlife Management 74:1513-1522. http://dx. doi.org/10.1111/j.1937-2817.2010.tb01279.x

Scott, P. E., T. L. DeVault, R. A. Bajema, and S. L. Lima. 2002. Grassland vegetation and bird abundances on reclaimed midwestern coal mines. Wildlife Society Bulletin 30:1006-1014.
Scott, P. E., and S. L. Lima. 2004. Exotic grasslands on reclaimed midwestern coal mines: an ornithological perspective. Weed Technology 18:1518-1521. http://dx.doi.org/10.1614/0890-037X (2004)018[1518:EGORMC]2.0.CO;2

Stauffer, G. E., D. R. Diefenbach, M. R. Marshall, and D. W. Brauning. 2011. Nest success of grassland sparrows on reclaimed surface mines. Journal of Wildlife Management 75:548-557. http:// dx.doi.org/10.1002/jwmg.70

Surface Mining Control and Reclamation Act of 1977. Public Law No. 95-87. 91 Stat. 445 (3 August 1977).

Thomas, E. H., M. C. Brittingham, and S. H. Stoleson. 2014. Conventional oil and gas development alters forest songbird communities. Journal of Wildlife Management 78:293-306. http:// dx.doi.org/10.1002/jwmg.662

Townsend, P. A., D. P. Helmers, C. C. Kingdon, B. E. McNeil, K. M. de Beurs, and K. N. Eshleman. 2009. Changes in the extent of surface mining and reclamation in the central Appalachians detected using a 1976-2006 Landsat time series. Remote Sensing of Environment 113:62-72. http://dx.doi.org/10.1016/j.rse.2008.08.012

Van Horne, B., and J. A. Wiens. 1991. Forest bird habitat suitability models and the development of general habitat models. Fish and Wildlife Research 8. U.S. Department of the Interior, Fish and Wildlife Service, Washington, D.C., USA.

Walk, J. W., and R. E. Warner. 1999. Effects of habitat area on the occurrence of grassland birds in Illinois. American Midland Naturalist 141:339-344. http://dx.doi.org/10.1674/0003-0031 (1999)141[0339:EOHAOT]2.0.CO;2

Weakland, C. A., and P. B. Wood. 2005. Cerulean Warbler (Dendroica cerulea) microhabitat and landscape-level habitat characteristics in southern West Virginia. Auk 122:497-508. http:// dx.doi.org/10.1642/0004-8038(2005)122[0497:CWDCMA]2.0.CO;2

Whitcomb, R. F., C. S. Robbins, J. F. Lynch, B. L. Klimkiewicz, and D. Bystrak. 1981. Effects of forest fragmentation on avifauna of the eastern deciduous forest. Pages 125-206 in R. L. Burgess and D. M. Sharpe, editors. Forest island dynamics in mandominated landscapes. Springer-Verlag, New York, New York, USA.

Wickham, J., P. B. Wood, M. C. Nicholson, W. Jenkins, D. Drunkenbrod, G. W. Suter, M. P. Strager, C. Mazzarella, W. Galloway, and J. Amos. 2013. The overlooked terrestrial impacts of mountaintop mining. BioScience 63:335-348. http://dx.doi. org/10.1525/bio.2013.63.5.7

Wood, P. B., and F. K. Ammer. 2015. Grasshopper Sparrow reproductive success and habitat use on reclaimed surface mines varies by age of reclamation. Wildlife Society Bulletin 39:512-520. http://dx.doi.org/10.1002/wsb.563

Wood, P. B., S. B. Bosworth, and R. Dettmers. 2006. Cerulean Warbler abundance and occurrence relative to large-scale edge and habitat characteristics. Condor 108:154-165. http://dx.doi. org/10.1650/0010-5422(2006)108[0154:CWAAOR]2.0.CO;2

Wood, P., J. Larkin, J. Mizel, C. Zipper, and P. Angel. 2013. Reforestation to enhance Appalachian mined lands as habitat for terrestrial wildlife. Forest Reclamation Advisory No. 10. U.S. 
Department of Interior, Office of Surface Mining Reclamation and Enforcement, Washington, D.C., USA.

Zar, J. H. 1999. Biostatistical analysis. Fourth edition. Prentice Hall, Upper Saddle River, New Jersey, USA.

Zipper, C. E., J. A. Burger, J. G. Skousen, P. N. Angel, C. D. Barton, V. Davis, and J. A. Franklin. 2011. Restoring forests and associated ecosystem services on Appalachian coal surface mines. Environmental Management 47:751-765. http://dx.doi.org/10.1007/ s00267-011-9670-Z 
Appendix 1. Alpha codes for species used in redundancy analysis grouped into their respective habitat guild. The Partners in Flight (PIF) Conservation Score ranges from 5 to 20 indicating least to greatest concern (Rosenberg et al. 2016).

\begin{tabular}{|c|c|c|c|c|}
\hline Habitat Guild & Common Name & Scientific Name & PIF Score & Alpha Code \\
\hline \multirow[t]{4}{*}{ Grassland } & Dickcissel & Spiza americana & 11 & DICK \\
\hline & Eastern Meadowlark & Sturnella magna & 11 & EAME \\
\hline & Grasshopper Sparrow & Ammodramus savannarum & 12 & GRSP \\
\hline & Horned Lark & Eremophila alpestris & 9 & HOLA \\
\hline \multirow[t]{16}{*}{ Shrubland } & Blue Grosbeak & Passerina caerulea & 8 & BLGR \\
\hline & Blue-winged Warbler & Vermivora cyanoptera & 13 & BWWA \\
\hline & Brown Thrasher & Toxostoma rufum & 10 & BRTH \\
\hline & Cedar Waxwing & Bombycilla cedrorum & 7 & CEDW \\
\hline & Chipping Sparrow & Spizella passerina & 8 & CHSP \\
\hline & Common Yellowthroat & Geothlypis trichas & 9 & COYE \\
\hline & Eastern Towhee & Pipilo erythrophthalmus & 11 & EATO \\
\hline & Field Sparrow & Spizella pusilla & 12 & FISP \\
\hline & Gray Catbird & Dumetella carolinensis & 8 & GRCA \\
\hline & Indigo Bunting & Passerina cyanea & 9 & INBU \\
\hline & Orchard Oriole & Icterus spurius & 10 & OROR \\
\hline & Prairie Warbler & Setophaga discolor & 13 & PRAW \\
\hline & White-eyed Vireo & Vireo griseus & 8 & WEVI \\
\hline & Willow Flycatcher & Empidonax traillii & 11 & WIFL \\
\hline & Yellow-breasted Chat & Icteria virens & 10 & $\mathrm{YBCH}$ \\
\hline & Yellow Warbler & Setophaga petechia & 8 & YEWA \\
\hline \multirow[t]{14}{*}{ Interior-edge } & American Redstart & Setophaga ruticilla & 10 & AMRE \\
\hline & Blue-gray Gnatcatcher & Polioptila caerulea & 7 & BGGN \\
\hline & Carolina Chickadee & Poecile carolinensis & 9 & $\mathrm{CACH}$ \\
\hline & Downy Woodpecker & Picoides pubescens & 7 & DOWO \\
\hline & Hooded Warbler & Setophaga citrina & 9 & HOWA \\
\hline & Northern Flicker & Colaptes auratus & 9 & NOFL \\
\hline & Northern Parula & Setophaga americana & 8 & NOPA \\
\hline & Red-bellied Woodpecker & Melanerpes carolinus & 7 & RBWO \\
\hline & Red-eyed Vireo & Vireo olivaceus & 6 & REVI \\
\hline & Ruby-throated Hummingbird & Archilochus colubris & 8 & RTHU \\
\hline & Summer Tanager & Piranga rubra & 9 & SUTA \\
\hline & Tufted Titmouse & Baeolophus bicolor & 7 & TUTI \\
\hline & Yellow-billed Cuckoo & Coccyzus americanus & 12 & YBCU \\
\hline & Yellow-throated Vireo & Vireo flavifrons & 9 & YTVI \\
\hline \multirow[t]{12}{*}{ Forest Interior } & Acadian Flycatcher & Empidonax virescens & 11 & ACFL \\
\hline & Black-and-white Warbler & Mniotilta varia & 11 & BAWW \\
\hline & Black-throated Green Warbler & Setophaga virens & 9 & BTNW \\
\hline & Blue-headed Vireo & Vireo solitarius & 7 & BHVI \\
\hline & Cerulean Warbler & Setophaga cerulea & 15 & CERW \\
\hline & Hairy Woodpecker & Picoides villosus & 6 & HAWO \\
\hline & Kentucky Warbler & Geothlypis formosa & 14 & KEWA \\
\hline & Louisiana Waterthrush & Parkesia motacilla & 12 & LOWA \\
\hline & Ovenbird & Seiurus aurocapilla & 9 & OVEN \\
\hline & Pileated Woodpecker & Dryocopus pileatus & 7 & PIWO \\
\hline & Scarlet Tanager & Piranga olivacea & 12 & SCTA \\
\hline & White-breasted Nuthatch & Sitta carolinensis & 6 & WBNU \\
\hline
\end{tabular}




\begin{tabular}{lllcl} 
& Worm-eating Warbler & Helmitheros vermivorum & 13 & WEWA \\
& Wood Thrush & Hylocichla mustelina & 14 & WOTH \\
& Yellow-throated Warbler & Setophaga dominica & 10 & YTWA \\
\hline Synanthropic & American Goldfinch & Spinus tristis & 7 & AMGO \\
& Brown-headed Cowbird & Molothrus ater & 7 & BHCO \\
& Blue Jay & Cyanocitta cristata & 8 & BLJA \\
& Carolina Wren & Thryothorus ludovicianus & 7 & CARW \\
& Eastern Phoebe & Sayornis phoebe & 8 & EAPH \\
& Killdeer & Charadrius vociferus & NA & KILL \\
& Mourning Dove & Zenaida macroura & 6 & MODO \\
& Northern Cardinal & Cardinalis cardinalis & 5 & NOCA \\
& Song Sparrow & Melospiza melodia & 8 & SOSP \\
\hline
\end{tabular}

